\title{
ELECTROCHEMICAL INCINERATION OF SHORT-CHAIN CARBOXYLIC ACIDS WITH NB-SUPPORTED BORON DOPED DIAMOND ANODE: SUPPORTING ELECTROLYTE EFFECT INTO THE ELECTROGENERATED OXIDANT SPECIES (HYDROXYL RADICALS, HYDROGEN PEROXIDE AND PERSULFATE)
}

\author{
Jorge Leandro Aquino de Queiroz, Dayanne Chianca de Moura ${ }^{a}$, Elaine Cristina M. de Moura Santos ${ }^{\mathrm{a}}$, Bernardo A. \\ Frontana-Uribe ${ }^{\mathrm{b}, \mathrm{c}}$ and Carlos A. Martínez-Huitle ${ }^{\mathrm{a}, *,(\mathbb{D})}$ \\ aUniversidade Federal do Rio Grande do Norte, Instituto de Química, 59072-970 Lagoa Nova - RN, Brasil \\ ${ }^{b}$ Centro Conjunto de Investigación en Química Sustentable UAEMéx-UNAM, Carretera Toluca-Ixtlahuaca Km. 14.5, 50200, \\ Toluca, México \\ 'Instituto de Química, Universidad Nacional Autónoma de México, Circuito Exterior, Ciudad Universitaria, 04510, México City, \\ México
}

Recebido em 24/05/2019; aceito em 15/10/2019; publicado na web em 03/03/2020

\begin{abstract}
This work describes the electrochemical oxidation study of three short chain carboxylic acids (acetic, oxalic and formic $0.18 \mathrm{~mol} \mathrm{~L}^{-1}$ ) using different electrolysis conditions (electrolyte composition and current density) in an electrochemical reactor fitted with niobiumsupported/BDD electrode (Nb/BBD) as anode and titanium plate as cathode. The experiments were focused to elucidate if the oxidation of these carboxylic acids involved a direct or a mediated oxidation pathway, as well as their electrochemical incineration efficiency using this electrochemical reactor. The amount of oxidizing species (hydroxyl radicals, hydrogen peroxide, and persulfate) produced at $\mathrm{Nb} / \mathrm{BDD}$ electrode was spectroscopically determined. The electrochemical kinetics study in $\mathrm{H}_{2} \mathrm{SO}_{4}$ and $\mathrm{HClO}_{4}$ solutions, as well as the chemical oxygen demand and total organic carbon analysis for each one of the carboxylic acids studied in both media, gave us information to propose a degradation mechanism for the electrochemical degradation of the carboxylic acids in each electrolytic media. The degradation in $\mathrm{H}_{2} \mathrm{SO}_{4}$ is promoted by the persulfate production, whereas in $\mathrm{HClO}_{4}$ by ${ }^{\circ} \mathrm{OH}$.
\end{abstract}

Keywords: carboxylic acids; electrooxidation; boron doped diamond; supporting electrolyte; oxidants.

\section{INTRODUCTION}

In the last years, the research of new efficient and cost-effective methods for the decontamination of waters has led to develop of several advanced oxidation processes (AOPs). Among the AOPs, electrochemical methods like direct electrochemical oxidation ${ }^{1,2}$ (DEO, the organic compounds interact with the anode surface) and indirect electrochemical oxidation ${ }^{3-5}$ (IEO, oxidation occurs via the reaction with electro-generated oxidant species) have received a lot of attention, due to their advantageous characteristics. ${ }^{1,2}$ Depending on the electrolysis conditions, different oxidant species can be electrochemically produced. For example using boron doped diamond electrode (BDDE) ${ }^{\circ} \mathrm{OH}$ can be efficiently formed during water discharge (Eq. 1), ${ }^{1,5}$ but others oxidants can be generated, depending on the supporting electrolyte composition. In this way, hydrogen peroxide $\left(\mathrm{H}_{2} \mathrm{O}_{2}\right)$ can be produced when dissolved molecular oxygen $\left(\mathrm{O}_{2}\right)$ is reduced ${ }^{1,6}$ or by the oxidation of water (Eq. 2) or combination of hydroxyl radicals (Eq. 3).,

$$
\begin{gathered}
\mathrm{H}_{2} \mathrm{O} \rightarrow \cdot \mathrm{OH}+\mathrm{H}^{+}+e^{-} \\
2 \mathrm{H}_{2} \mathrm{O} \rightarrow \mathrm{H}_{2} \mathrm{O}_{2}+2 e^{-}+2 \mathrm{H}^{+} \\
2 \cdot \mathrm{OH} \rightarrow \mathrm{H}_{2} \mathrm{O}_{2}
\end{gathered}
$$

Persulfates are formed by combination of sulfate radicals, produced by direct electron transfer (Eq. 4) or reaction of sulfate anion with hydroxyl radical (Eq. 5 to 7 ) ${ }^{8}$ Sulfate radicals also can favor the organic compounds degradation as shown in Eq. 8. ${ }^{9}$ Both species acts as strong oxidants for removing efficiently the organic matter in solution. When the solutions contain sulfates, persulfates

*e-mail: carlosmh@quimica.ufrn.br
$\left(\mathrm{S}_{2} \mathrm{O}_{8}{ }^{2-}\right)$ play an important role during the electrochemical degradation of organic pollutants (Eq. 9)., ${ }^{2,5}$

$$
\begin{gathered}
2 \mathrm{SO}_{4}^{-} \rightarrow \mathrm{S}_{2} \mathrm{O}_{8}^{2-} \\
\mathrm{SO}_{4}^{2-}+\mathrm{OH}^{-\cdot} \rightarrow \mathrm{SO}_{4}^{-\cdot}+\mathrm{OH}^{-} \\
\mathrm{H}_{2} \mathrm{SO}_{4}+{ }^{-} \mathrm{OH} \rightarrow \mathrm{SO}_{4}^{-\cdot}+\mathrm{H}_{3} \mathrm{O}^{+} \\
\mathrm{SO}_{4}^{-\cdot}+\mathrm{SO}_{4}^{-\cdot} \rightarrow \mathrm{S}_{2} \mathrm{O}_{8}{ }^{2-} \\
\mathrm{SO}_{4}^{-\cdot}+\text { organic compound } \rightarrow \\
\text { Oxidation products } \rightarrow \rightarrow \mathrm{CO}_{2}+\mathrm{H}_{2} \mathrm{O} \\
\mathrm{S}_{2} \mathrm{O}_{8}{ }^{2-}+\text { organic compound } \rightarrow \\
\text { Oxidation products } \rightarrow \rightarrow \mathrm{CO}_{2}+\mathrm{H}_{2} \mathrm{O}
\end{gathered}
$$

Peroxide, persulphate and hydroxyl radical can all be considered green oxidants because the products of their electronic transfer are harmless and can be part of a catalytic cycle. Thanks to these characteristics, its use is very attractive in the treatment of contaminated effluents. ${ }^{10}$ The electrogeneration of these oxidants by using silicon-supported/BDD electrode (Si/BBD) as anode has been confirmed. ${ }^{5,9}$ Then, in consideration of the fact that, the electrode contains an electrocatalytic conductive diamond layer, it was of our interest to study the effect of other material support for the BDD on the oxidants produced by the electrolysis. In this way, the change from $\mathrm{Si} / \mathrm{BDD}$ to $\mathrm{Nb} / \mathrm{BDD}$ should not involve dramatic changes in the results if the main degradation reaction pathways follow homogeneous reactions generated by the electrogenated oxidants, on the other hand if direct electrolysis occurs the results should be very different. Nevertheless, both anodes have been successfully used to degrade organic compounds (e.g.: pharmaceuticals, dyes, petroleum, pesticides and herbicides, ${ }^{1-5,11-15}$ no attempts have been reported yet regarding the use of different electrolytes to promote the electrogeneration of different oxidants at $\mathrm{Nb} / \mathrm{BDD}$ anode. Thus, this investigation describes the comparative study of two supporting 
electrolytes $\left(\mathrm{H}_{2} \mathrm{SO}_{4}\right.$ and $\left.\mathrm{HClO}_{4}\right)$ to determine its role during the electrochemical oxidation of short-chain carboxylic acids acetic acid (AA), oxalic acid (OA) and formic acid (FA) at Nb/BDD anode under different current densities. This strategy let to understand the formation and role of the strong oxidant species electrogenerated in the experimental conditions. The short-chain carboxylic acids were chosen as model compounds, because they have been identified as intermediates or final products of in various AOPs, since they are more difficult to oxidize than the initial contaminants. ${ }^{4,16}$ This characteristic make of them interesting compounds to determine the limitation of the AOPs as well as useful to the determination of reactions mechanisms. ${ }^{18-20}$

\section{EXPERIMENTAL}

\section{Materials}

The short-chain carboxylic acids (AA, OA and FA) were purchased from J. T. Baker and used without further purification. Distilled water was used in all solutions and experiments. The synthetic solutions (FA $0.18 \mathrm{~mol} \mathrm{~L}^{-1}$, AA $0.18 \mathrm{~mol} \mathrm{~L}^{-1}$ and OA $0.18 \mathrm{~mol} \mathrm{~L}^{-1}$ ) were prepared using $0.25 \mathrm{~mol} \mathrm{~L}^{-1} \mathrm{HClO}_{4}$ and $\mathrm{H}_{2} \mathrm{SO}_{4}$ as supporting electrolytes.

\section{Electrochemical measurements}

Linear polarization analyses were performed at room temperature $\left(25^{\circ} \mathrm{C}\right)$ with a Metrohm AUTOLAB potentiostat model PGSTAT302N. The three-electrode cell was constituted by a $\mathrm{Ag} / \mathrm{AgCl}\left(\mathrm{KCl} 3 \mathrm{~mol} \mathrm{~L}^{-1}\right)$ as reference electrode, $\mathrm{Pt}$ wire as the counter electrode and $\mathrm{Nb} / \mathrm{BDD}$ (Metakem, Germany) as working electrode with an exposed geometric area of $1 \mathrm{~cm}^{2}$. Quasi-steady polarization curves were carried out at a scan rate of $50 \mathrm{mV} \mathrm{s}^{-1}$ and with a $2.44 \mathrm{mV}$ step potential, by using the aforementioned BDD working electrode in $0.25 \mathrm{~mol} \mathrm{~L}^{-1} \mathrm{HClO}_{4}$ and $\mathrm{H}_{2} \mathrm{SO}_{4}$ as supporting electrolytes.

\section{Large scale electrolysis system}

Bulk EO were carried out in a single compartment undivided cell (batch mode) containing $0.5 \mathrm{~L}$ of solution under constant stirring and galvanostatic conditions with a MINIPA MPL-3305M power supply. $\mathrm{Nb} / \mathrm{BDD}$ film (Metakem, Germany) was used as anode, while titanium was employed as cathode. The electrodes were plates with a geometric area of about $18 \mathrm{~cm}^{2}$ and were placed parallel each other with an inter-electrode gap of $1.2 \mathrm{~cm}$. The experiments were performed at $25^{\circ} \mathrm{C}$ (thermostatic bath), using a current density (j) range of 30,60 , 90 and $120 \mathrm{~mA} \mathrm{~cm}^{-2}$ during $240 \mathrm{~min}$.

\section{Analytical methods}

Chemical oxygen demand (COD) and total organic carbon (TOC): The short-chain carboxylic acids concentration elimination was monitored by COD which was determined by pre-COD dosage tubes and these were then heated in a Hanna Instruments HI 839800 thermo reactor for $2 \mathrm{~h}$ at $150{ }^{\circ} \mathrm{C}$. Shimadzu TOC-V CPH was used to quantify TOC in samples.

Hydroxyl radicals determination: Hydroxyl radicals were detected by the bleaching of N,N-dimethyl-4-nitrosoaniline (RNO). The original yellow solution was decolorized through reaction between RNO and ${ }^{\circ} \mathrm{OH}$ forming a colorless adduct. ${ }^{21}$ The bleaching of the $2 \times 10^{-5} \mathrm{~mol} \mathrm{~L}^{-1} \mathrm{RNO}$ solution in $0.25 \mathrm{~mol} \mathrm{~L}^{-1} \mathrm{H}_{2} \mathrm{SO}_{4}$ and in $0.25 \mathrm{~mol} \mathrm{~L}^{-1} \mathrm{HClO}_{4}$ was followed by using the spectrophotometer previously described reading the absorbance at $350 \mathrm{~nm}$.
Hydrogen peroxide determination: The spectrophotometric methodology using ammonium metavanadate proposed by Nogueira et al. ${ }^{22}$ was used for detection and quantification of $\mathrm{H}_{2} \mathrm{O}_{2}$ formed in solution. Also, some parameters described by Oliveira et al. ${ }^{23}$ were used.

Persulfates determination: The spectrophotometric methodology proposed by Liang et al. ${ }^{24}$ was used for persulfate quantification.

\section{Efficiency parameters}

Energy consumption: Energetic requirements of the each experiment were estimated (in $\mathrm{kWh} \mathrm{m}^{-3}$ ) means of the expression: ${ }^{4}$

$$
\text { Energy consumption }=\frac{\Delta E c \times I \times T}{1000} \times V_{s}
$$

where $t$ is the time of electrolysis (h), $E c(\mathrm{~V})$ and $I(\mathrm{~A})$ are the average cell voltage and the electrolysis current, respectively; and $V_{s}$ is the sample volume $\left(\mathrm{m}^{3}\right)$.

Total current efficiency (TCE): Percentage of TCE for electrochemical oxidations of the carboxylic was estimated by using the initial and final COD values, following relationship: ${ }^{4}$

$$
\operatorname{TCE}(\%)=F V\left(\frac{C O D_{0}-C O D_{t}}{8 I \Delta t}\right) \times 100
$$

where $I$ is the current (A), $F$ the Faraday constant $\left(96,487 \mathrm{C} \mathrm{mol}^{-1}\right)$, $V$ is the electrolyte volume $\left(\mathrm{dm}^{3}\right), 8$ is the oxygen equivalent mass (g eq. ${ }^{-1}$ ) and $t$ is the electrolysis time, allowing for a global determination of the overall efficiency of the process.

Mineralization current efficiency (MCE): This parameter was calculated using the relationship established by Brillas et al. ${ }^{3,4}$

$$
\operatorname{MCE}(\%)=\frac{n F V_{s} \Delta(T O C)_{\exp }}{4.32 \times 10^{7} \mathrm{mIt}} \times 100
$$

were $n$ is the number of electrons consumed in the oxidation of the compound ( 2 for formic and oxalic and 8 for acetic acid), $F$ is the Faraday constant $\left(=96487 \mathrm{C} \mathrm{mol}^{-1}\right), V_{s}$ is the solution volume (L), $\Delta(\text { TOC })_{\exp }$ is the experimental TOC decay $\left(\mathrm{mg} \mathrm{L}^{-1}\right), 4.32 \times 10^{7}$ is a conversion factor $\left(=3600 \mathrm{~s} \mathrm{~h}^{-1} 12000 \mathrm{mg}\right.$ of $\left.\mathrm{C} \mathrm{mol}^{-1}\right), \mathrm{m}$ is the number of carbon atoms in the molecule ( 1 for FA and 2 for AA and OA), $I$ is the applied current (A) and $t$ is the time (h). The reactions of oxidation of formic, acetic and oxalic acids, respectively, are shown in Eq. $13-15:^{25}$

$$
\begin{gathered}
\mathrm{HCOOH} \rightarrow 2 \mathrm{CO}_{2}+2 \mathrm{H}^{+}+2 e^{-} \\
\mathrm{CH}_{3} \mathrm{COOH}+2 \mathrm{H}_{2} \mathrm{O} \rightarrow 2 \mathrm{CO}_{2}+8 \mathrm{H}^{+}+8 e^{-} \\
(\mathrm{COOH})_{2} \rightarrow 2 \mathrm{CO}_{2}+2 \mathrm{H}^{+}+2 e^{-}
\end{gathered}
$$

\section{RESULTS AND DISCUSSION}

\section{Supporting electrolyte effect into the electrogenerated of oxidants species (hydroxyl radicals, hydrogen peroxide and persulfate)}

UV-visible measurements were used for detecting hydroxyl radicals formed at $\mathrm{Nb} / \mathrm{BDD}$ electrode during water anodic discharge. The indirect technique for the detection of low concentrations of hydroxyl radicals is carried out with a spin trapping (RNO) compound in order to produce a more stable radical (spin adduct). The used compound for this task is particularly advantageous and selective, because under these conditions of concentration and $\mathrm{pH}$ it is electrochemically inactive at positive potentials, and the addition 
reaction occurs at a very high rate constant $\left(1.3 \times 10^{10} \mathrm{~L} \mathrm{~mol}^{-1} \mathrm{~S}^{-1}\right){ }^{20,21}$ Figure 1 shows the adsorption spectrum of aqueous RNO solution $\left(2 \times 10^{-5} \mathrm{~mol} \mathrm{~L}^{-1}\right)$ during galvanostatic electrolysis with $\mathrm{Nb} / \mathrm{BDD}$ anode by applying $60 \mathrm{~mA} \mathrm{~cm}-2$, in $0.25 \mathrm{~mol} \mathrm{~L}^{-1} \mathrm{H}_{2} \mathrm{SO}_{4}$ (Figure 1a) and $\mathrm{HClO}_{4}$ (Figure $1 \mathrm{~b}$ ) as supporting electrolytes.

A decrease in absorbance at $350 \mathrm{~nm}$ during electrolysis is observed in both medium. Although the results showed that, there was accumulation of ${ }^{\circ} \mathrm{OH}$ radicals at the $\mathrm{Nb} / \mathrm{BDD}$ anode surface, when $\mathrm{H}_{2} \mathrm{SO}_{4}$ was used as supporting electrolyte RNO absorbance decreases faster $(5 \mathrm{~min})$, whereas with $\mathrm{HClO}_{4}$ medium requires more almost $3 \mathrm{hrs}$. This effect indicates that, when electrolysis is carried out in $\mathrm{H}_{2} \mathrm{SO}_{4}$, the adduct formed by reaction between RNO and ${ }^{\circ} \mathrm{OH}$ radicals is formed faster and can be in first instance be rationalized as a major production of ${ }^{\circ} \mathrm{OH}$ species. However, as was mentioned in the introduction, in a solution containing with sulfates the electrogeneration of persulfate ions is feasible.

Taking into consideration this fact, the persulfate formation is attained in parallel, promoting the degradation of RNO under these experimental conditions, and consequently, accelerating the disappearance of RNO absorption peak. In fact, the UV-vis spectrum showed the existence of intermediates that absorb irradiation approximately at 190 and $250 \mathrm{~nm}$. Meanwhile, at $\mathrm{HClO}_{4}$, the results clearly demonstrated that, only ${ }^{\circ} \mathrm{OH}$ radicals are produced at $\mathrm{BDD}$ surface, which react with RNO to form adduct species, avoiding their degradation. In fact, no absorption bands were achieved at wavelengths below $280 \mathrm{~nm}$.

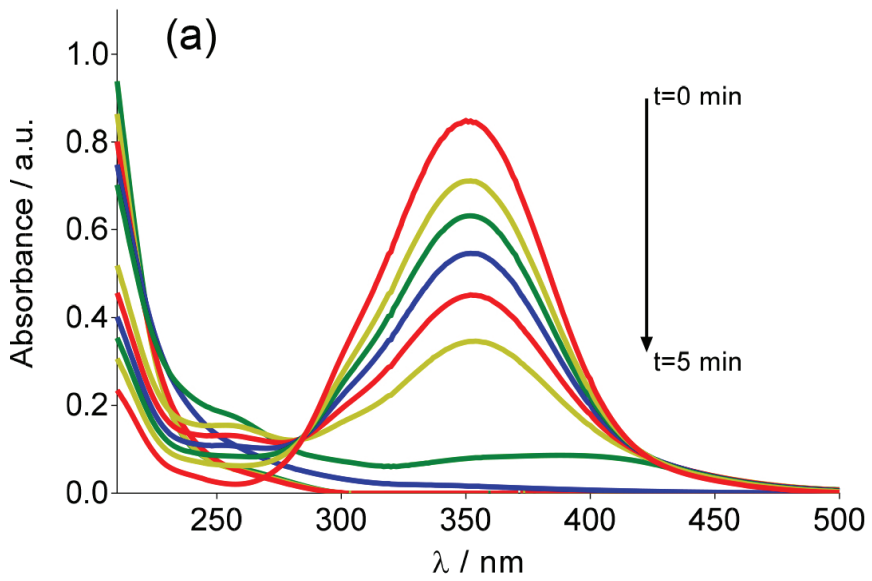

Similar behavior was achieved at all $j$ values, indicating that significant concentrations of ${ }^{\circ} \mathrm{OH}$ radicals are electrochemically generated in $\mathrm{HClO}_{4}$, but their concentration depends on the $j$ used (Figure 2). In fact, higher $j$ provoked a more rapid disappearance of the RNO adsorption, confirming that in these conditions the production of ${ }^{\circ} \mathrm{OH}$ radicals was favored. These results are in agreement with the proposed model by Comninellis in which the BDD electrocatalytic material is considered a nonactive anode due to the significant production of ${ }^{\circ} \mathrm{OH}$ radicals, physically adsorbed, that favor the complete combustion of organic pollutants. ${ }^{1,5,7,21}$

The formation of other oxidants than ${ }^{\circ} \mathrm{OH}$ at the BDD surface during the electrolysis is feasible, for example $\mathrm{H}_{2} \mathrm{O}_{2}$ and $\mathrm{S}_{2} \mathrm{O}_{8}{ }^{2-}$ (Eq. 1-9). ${ }^{25,26}$ For this reason, its quantification is necessary to have a better picture of the oxidizing agents' role during carboxylic acids degradation. Figure 3 shows the evolution of $\mathrm{H}_{2} \mathrm{O}_{2}$ concentration as a function of electrolysis time for BDD electrodes by applying different $j$ in $\mathrm{H}_{2} \mathrm{SO}_{4}$ (Figure $3 \mathrm{a}$ ) and $\mathrm{HClO}_{4}$ (Figure $3 \mathrm{~b}$ ) at $25^{\circ} \mathrm{C}$. This figure shows clearly that the production of $\mathrm{H}_{2} \mathrm{O}_{2}$ is significantly higher at $\mathrm{HClO}_{4}$ medium than that formed at $\mathrm{H}_{2} \mathrm{SO}_{4}$. It also increases when an increase on the $j$ is attained at $\mathrm{HClO}_{4}$.

This behavior is can be attributed to the electrochemical formation of free hydroxyl radicals at BDD electrode surface because, the higher concentration ${ }^{\circ} \mathrm{OH}$ radicals the higher the recombination between them to form $\mathrm{H}_{2} \mathrm{O}_{2}$ (Eq. 3). However, it is also expected that after its formation, hydrogen peroxide in

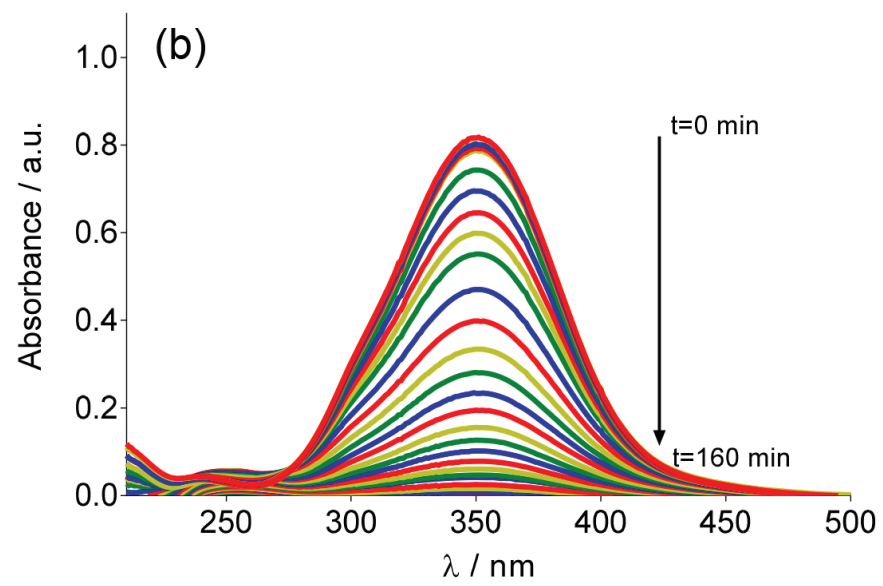

Figure 1. Adsorption spectra of aqueous RNO solution $\left(2 \times 10^{-5} \mathrm{~mol} \mathrm{L^{-1 } )}\right.$ obtained at different electrolysis-time intervals under galvanostatic conditions, in (a) $0.25 \mathrm{~mol} \mathrm{~L}^{-1} \mathrm{H}_{2} \mathrm{SO}_{4}$ and (b) $0.25 \mathrm{~mol} \mathrm{~L}^{-1} \mathrm{HClO}_{4}$ as supporting electrolytes, at $\mathrm{Nb} / \mathrm{BDD}$ anode by applying $60 \mathrm{~mA} \mathrm{~cm}^{-2}$ at $25^{\circ} \mathrm{C}$
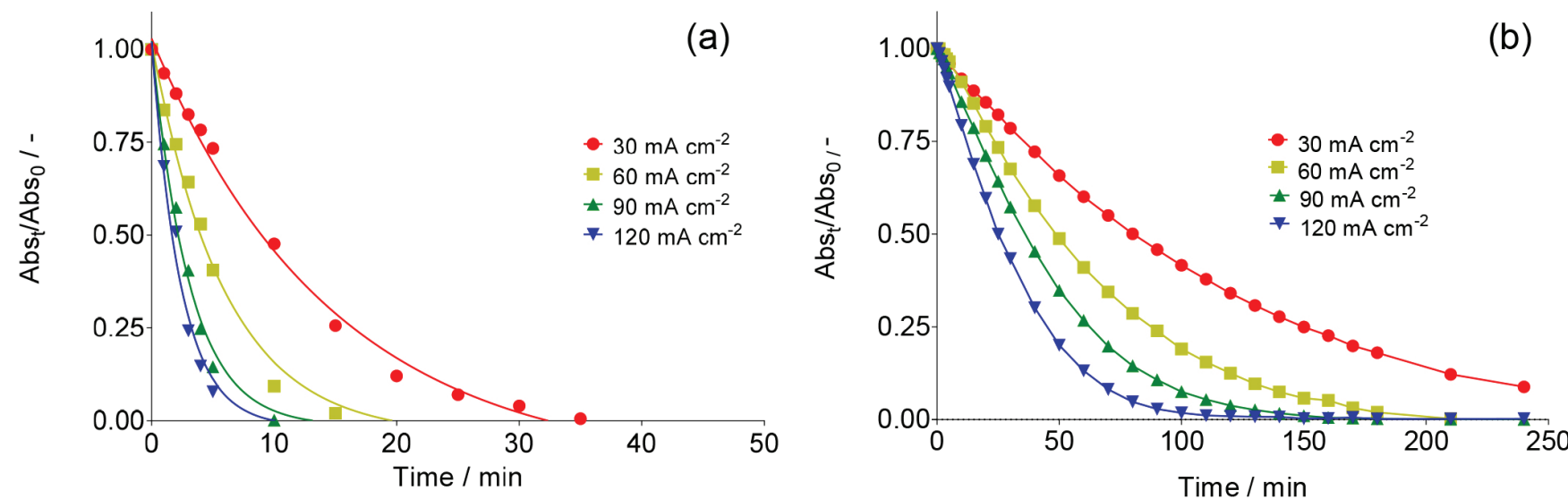

Figure 2. Normalized absorbance decay of RNO solution as consequence of hydroxyl radicals electrogeneration at Nb/BDD anode by applying 30, 60, 90 and $120 \mathrm{~mA} \mathrm{~cm}^{-2}$ during electrolysis in (a) $0.25 \mathrm{~mol} \mathrm{~L}^{-1} \mathrm{H}_{2} \mathrm{SO}_{4}$ and (b) $0.25 \mathrm{~mol} \mathrm{~L}^{-1} \mathrm{HClO}_{4}$ at $25^{\circ} \mathrm{C}$ 
solution can be decomposed through reaction at the anode surface (Eq. 16) or cathode surface (Eq. 17); therefore its concentration reaches a plateau.

$$
\begin{gathered}
\mathrm{H}_{2} \mathrm{O}_{2} \rightarrow \mathrm{O}_{2}+2 \mathrm{H}^{+}+2 \mathrm{e}^{-} \\
\mathrm{H}_{2} \mathrm{O}_{2}+2 \mathrm{H}^{+}+2 \mathrm{e}^{-} \rightarrow 2 \mathrm{H}_{2} \mathrm{O}
\end{gathered}
$$

Concentrations of $\mathrm{H}_{2} \mathrm{O}_{2}$ are lower at $\mathrm{Nb} / \mathrm{BDD}$ than those reported in the literature for $\mathrm{Si} / \mathrm{BDD},{ }^{7}$ suggesting that the electrochemical activity for hydrogen peroxide formation is minor.

In $\mathrm{H}_{2} \mathrm{SO}_{4}$ medium, the main reactions at water discharge should be the formation of persulfate (Eqs. 4 and 7) via oxidation of sulfate ions in solution ${ }^{7,27}$ and the oxygen evolution (Eq. 18). In contrast, using $\mathrm{HClO}_{4}$ the main reaction at water discharge should be oxygen evolution (Eq. with concomitant production of ${ }^{\circ} \mathrm{OH}$ radicals, due to water oxidation (Equations 1 and 15 respectively).

$$
2 \mathrm{H}_{2} \mathrm{O} \rightarrow \mathrm{O}_{2}+4 \mathrm{e}^{-}+4 \mathrm{H}^{+}
$$

To evaluate the amount of persulfate formed at water oxidation in $\mathrm{H}_{2} \mathrm{SO}_{4}$, electrolyzes at different current density were performed. Concentration of these species was determined in the anolyte during electrolyzes by ISCO method. ${ }^{24}$ Figure 4 shows the influence of current density on the $\mathrm{S}_{2} \mathrm{O}_{8}{ }^{2-}$ concentration. As can be observed, an increase on the $\mathrm{S}_{2} \mathrm{O}_{8}{ }^{2-}$ concentration is achieved when $j$ increases from 30 to $90 \mathrm{~mA} \mathrm{~cm}^{-2}$. However, when higher $j$ is applied, a decrease on the persulfate concentration is attained. This behavior is due to the

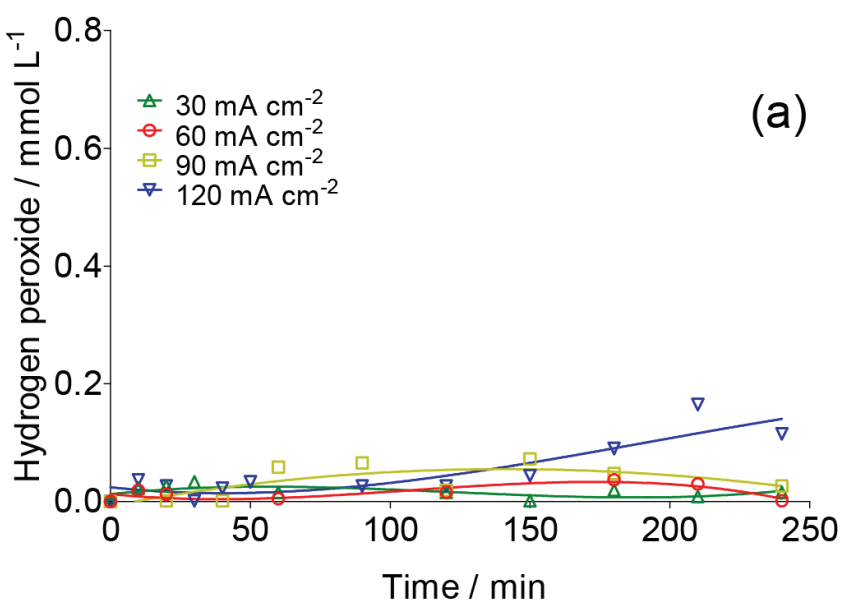

faster oxygen evolution at higher $j$, decreasing the electrosynthesis of persulfate.

In order to gain insight about these important reactions in both supporting electrolytes, potentiodynamic measurements of the water discharge were carried out. Figure 5 shows linear polarization curves and the corresponding Tafel plots of $\mathrm{Nb} / \mathrm{BDD}$ electrode obtained in $\mathrm{HClO}_{4}$ and $\mathrm{H}_{2} \mathrm{SO}_{4}$ at a scan rate of $50 \mathrm{mV} \mathrm{s}^{-1}$. Current-potential curves are almost identical, although the reactions that take place in $\mathrm{HClO}_{4}$ and $\mathrm{H}_{2} \mathrm{SO}_{4}$ media are different. The value of Tafel slope is almost the same for both media (ca. $0.81 \mathrm{~V} \mathrm{decade}^{-1}$ ), being 3.5-folds higher than $\mathrm{Si} / \mathrm{BDD} .^{7}$ Therefore, silicon supported BDD is oxidizes faster water and the difference probably is due to the different semimetal/ semiconductor properties between both diamond films.

Taken into consideration the data obtained in potentiodynamic measurements can be concluded that even if the main reaction products are different $\left(\mathrm{O}_{2}\right.$ and ${ }^{\circ} \mathrm{OH}$ radicals in $\mathrm{HClO}_{4}$ and $\mathrm{O}_{2}$ and $\mathrm{S}_{2} \mathrm{O}_{8}{ }^{2-}$ in $\mathrm{H}_{2} \mathrm{SO}_{4}$ ); the same electrochemical reaction is generating them in both electrolytes. Then, this indicates that the first step during water discharge on $\mathrm{Nb} / \mathrm{BDD}$ electrode is the $\mathrm{O}_{2}$ evolution (Eq. 16 or 18) with simultaneous generation of hydroxyl radicals (Eq. 1). After, and depending on the supporting electrolyte, the electrogenerated hydroxyl radicals can react to produce persulfate in case of $\mathrm{H}_{2} \mathrm{SO}_{4}$ electrolyte (Eq. 5 and 6), or can generate $\mathrm{H}_{2} \mathrm{O}_{2}$ by the reaction of hydroxyl radicals in case of $\mathrm{HClO}_{4}$ electrolyte (Eq. 3). In both cases, recalcitrant organic matter degradation follows indirect electrochemical oxidation pathways that include oxidation with $\cdot \mathrm{OH}$ and the other electrogenerated strong oxidants. It is important

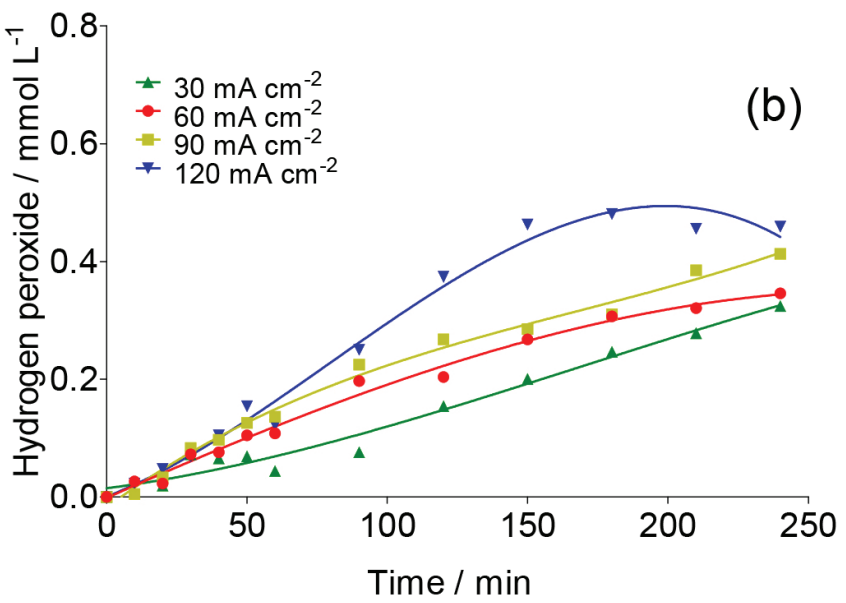

Figure 3. Concentration of electrogenerated $\mathrm{H}_{2} \mathrm{O}_{2}$ at $\mathrm{Nb} / \mathrm{BDD}$ surface in (a) $0.25 \mathrm{~mol} \mathrm{~L}^{-1} \mathrm{H}_{2} \mathrm{SO}_{4}$ and (b) $0.25 \mathrm{~mol} \mathrm{~L}^{-1} \mathrm{HClO}_{4}$ by applying 30 , 60 , 90 and $120 \mathrm{~mA} \mathrm{~cm} \mathrm{~cm}^{-2}$ at $25^{\circ} \mathrm{C}$

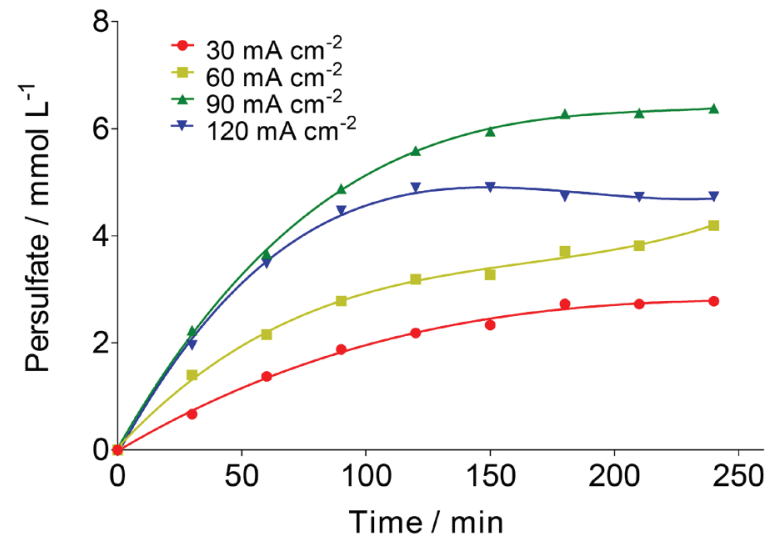

Figure 4. Electrogenerated $\mathrm{S}_{2} \mathrm{O}_{8}{ }^{2-}$ at $\mathrm{BDD}$ anode by applying 30, 60, 90 and $120 \mathrm{~mA} \mathrm{~cm} \mathrm{~cm}^{-2}$ during electrolysis in $0.25 \mathrm{~mol} \mathrm{~L}^{-1} \mathrm{H}_{2} \mathrm{SO}_{4}$ at $25^{\circ} \mathrm{C}$

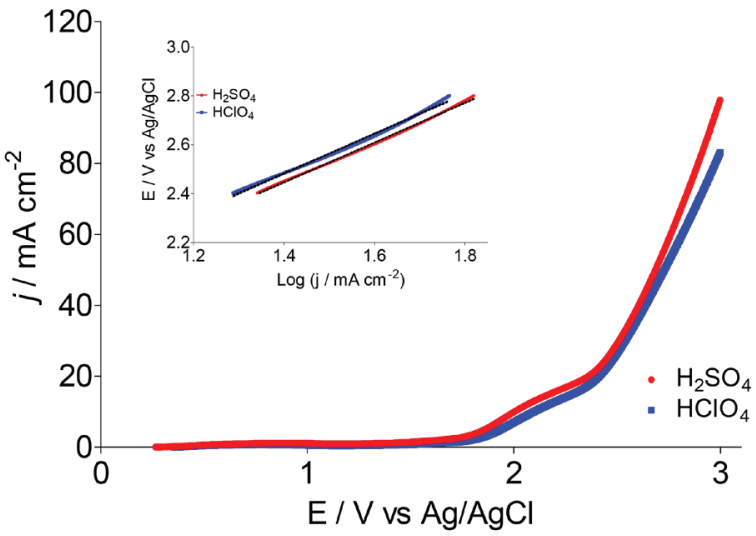

Figure 5. Polarization curves and Tafel analysis for $\mathrm{Nb} / \mathrm{BDD}$ electrode in $0.25 \mathrm{~mol} \mathrm{~L}^{-1} \mathrm{H}_{2} \mathrm{SO}_{4}$ and $0.25 \mathrm{~mol} \mathrm{~L}^{-1} \mathrm{HClO}_{4}$ at $50 \mathrm{mV} \mathrm{s}^{-1}$ at $25^{\circ} \mathrm{C}$ 
to remark that, in the case of $\mathrm{H}_{2} \mathrm{SO}_{4}$ medium, the co-existence of direct oxidation mechanism cannot be feasible due to the significant production of persulfate and ${ }^{\circ} \mathrm{OH}$ radicals at diamond surface.

\section{COD decay}

In order to determine the efficiency of the EO on very difficult to oxidize (recalcitrant) short-chain carboxylic acids (AA, OA and FA) and to understand the participation of the strong oxidants produced at $\mathrm{Nb} / \mathrm{BDD}$ surface in both supporting electrolytes, bulk electrolyzes were carried out. COD and TOC were monitored during $240 \mathrm{~min}$ of electrolysis at different $j$ values. Figure 6 shows the COD decays for the studied carboxylic acids as a function of time at the $\mathrm{Nb} / \mathrm{BDD}$ anode. The results demonstrate that COD removal is strongly influenced by the $j$ as well as the carboxylic acid added
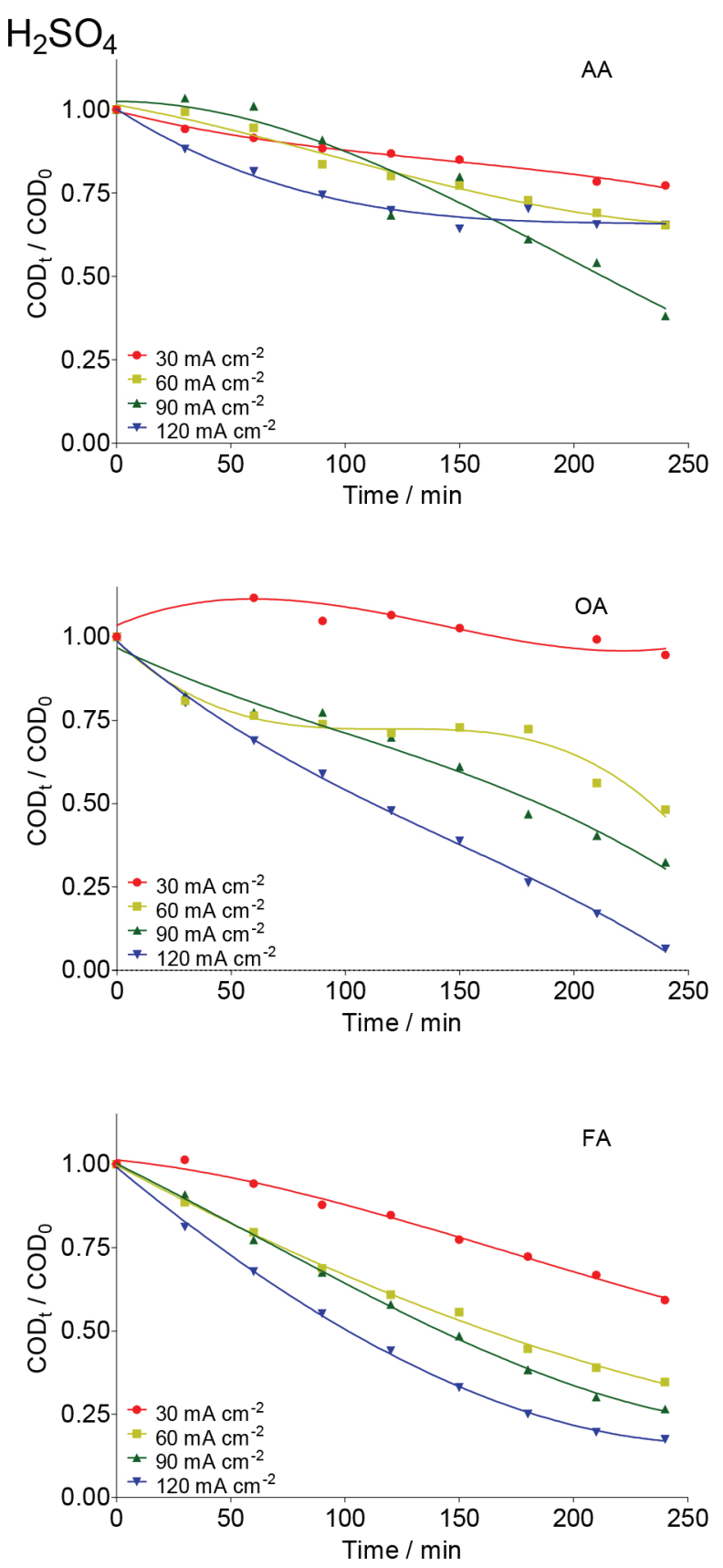

to the electrolyte. In the case of $\mathrm{AA}$ in $\mathrm{H}_{2} \mathrm{SO}_{4}$ media, no significant COD removals were achieved at 30 and $60 \mathrm{~mA} \mathrm{~cm}^{-2}(\approx 26 \%$ of COD removal was achieved in each case). At $90 \mathrm{~mA} \mathrm{~cm}^{-2}, 50 \%$ of COD was attained; but an increase on the $j\left(120 \mathrm{~mA} \mathrm{~cm}^{-2}\right)$ promotes a decrease on the COD removal achieving up to $25 \%$. This behavior suggests that the BDD anode favors a set of electrochemical reactions, involving most probably the oxygen evolution and persulfate formation as was concluded in the previous section (Figure 4). ${ }^{7,19,20,28-30}$ Indirect oxidation of AA via $\cdot \mathrm{OH}$ and persulfate could be attained by applying 30,60 and $90 \mathrm{~mA} \mathrm{~cm}^{-2}$, however, the production of some intermediates more difficult to oxidize (small amounts of FA and traces of OA), ${ }^{30,31}$ limit an higher COD removal. Conversely, with $120 \mathrm{~mA} \mathrm{~cm}^{-2}$ oxygen evolution was favored, reducing the production of persulfates (see, Figure 4), as well as hydroxyl radicals and consequently, limiting an efficient degradation of AA and its intermediates. Comparing these
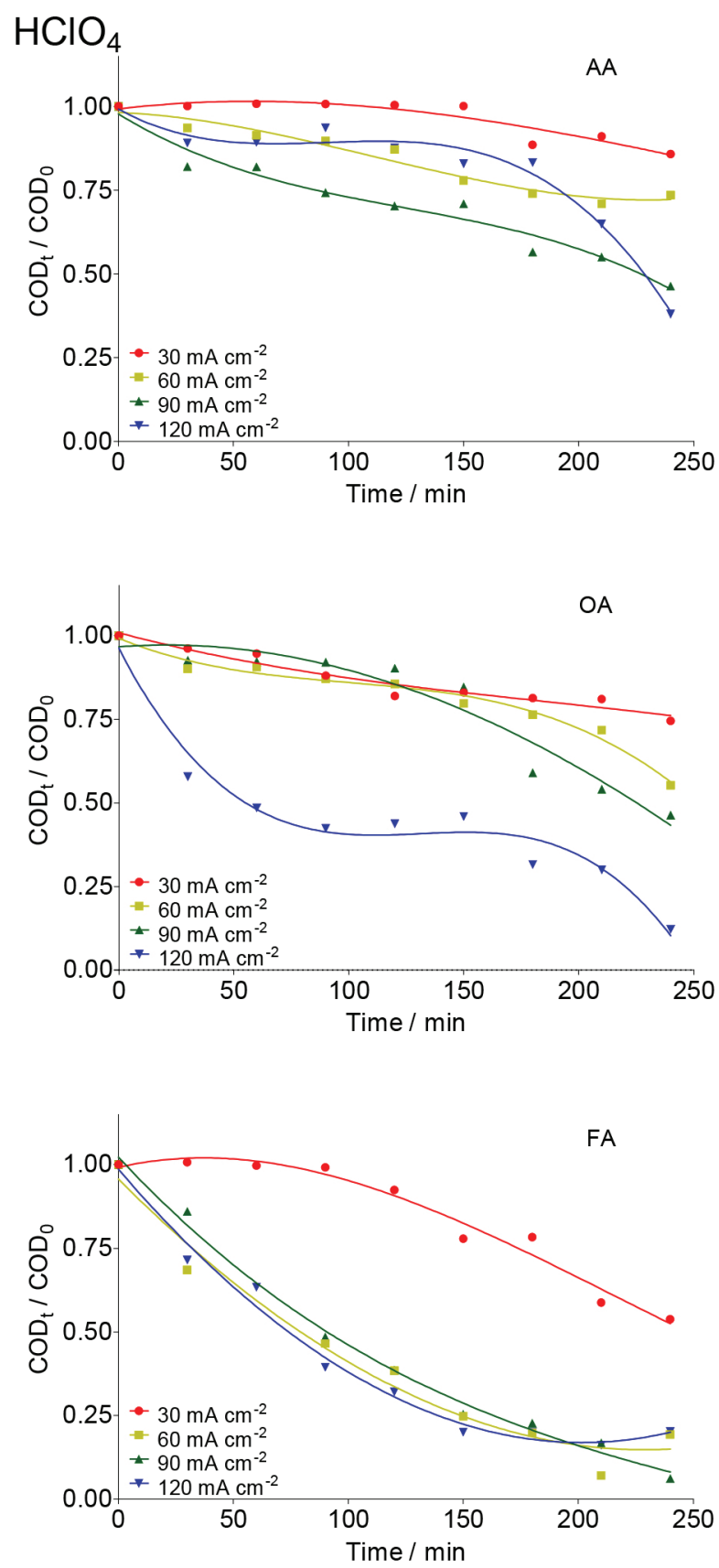

Figure 6. Effect of $j$ on the normalized COD decay as a function of electrolysis time during the EO of AA, OA and FA at Nb/BDD anode surface in 0.25 mol $L^{-1}$ $\mathrm{H}_{2} \mathrm{SO}_{4}$ (left) and $0.25 \mathrm{~mol} \mathrm{~L}^{-1} \mathrm{HClO}_{4}$ (right) applying 30, 60, 90 and $120 \mathrm{~mA} \mathrm{~cm}^{-2}$ 
results with the behavior observed at $\mathrm{HClO}_{4}$, very similar elimination profiles of AA were reached (Figure 6), but slight differences (in terms of efficiency) were observed at lower $j$, where degradation rate was slightly faster when sulfate medium is used. This experiment indicates that AA can be oxidized by the strong oxidants generated in both media, but the production of persulfates in sulfate medium, oxidizes faster in the bulk the short-chain carboxylic acid.

During $\mathrm{Nb} / \mathrm{BDD}$ electrolysis for OA elimination (Figure 6) in $\mathrm{H}_{2} \mathrm{SO}_{4}$, no significant COD removal was observed at $30 \mathrm{~mA} \mathrm{~cm} \mathrm{~cm}^{-2}$ $(\approx 5 \%)$. However, when an increase on the $j$ is attained, the elimination of OA from solution was gradually increased, achieving 50\%, 70\% and $98 \%$ of COD removals after $240 \mathrm{~min}$ by applying 60,90 and 120 $\mathrm{mA} \mathrm{cm}^{-2}$, respectively. This result indicates that this carboxylic acid requires high concentration of strong oxidant $\left({ }^{\circ} \mathrm{OH}\right.$ and $\mathrm{H}_{2} \mathrm{O}_{2}$ in $\mathrm{HClO}_{4}$ or ${ }^{\circ} \mathrm{OH}$ and $\mathrm{S}_{2} \mathrm{O}_{8}{ }^{2-}$ in $\mathrm{H}_{2} \mathrm{SO}_{4}$ ) to be degraded Conversely, at $\mathrm{HClO}_{4}$, lower COD decays were achieved at 30,60 and $90 \mathrm{~mA} \mathrm{~cm}^{-2}$, while an $87 \%$ of COD was achieved at $120 \mathrm{~mA} \mathrm{~cm}^{-2}$. In the former behavior, it is clearly that a synergic effect due to the participation of strong oxidants ( ${ }^{\circ} \mathrm{OH}$ and persulfate) promotes a quick elimination of OA (Eq. 19). Meanwhile, the oxidation process, in $\mathrm{HClO}_{4}$, competes with the side reaction of oxygen evolution (Eq. 18) and $\mathrm{H}_{2} \mathrm{O}_{2}$ production (considered a weaker oxidant), avoiding a significant elimination of $\mathrm{OA}$, in the proximity of the electrode surface and/or in the bulk of the electrolyte. ${ }^{19,25,29}$

$$
\mathrm{C}_{2} \mathrm{O}_{4} \mathrm{H}_{2}+{ }^{\cdot} \mathrm{OH} / \mathrm{S}_{2} \mathrm{O}_{8}{ }^{2-} \rightarrow \mathrm{CO}_{2}+\mathrm{H}_{2} \mathrm{O}
$$

Figure 6 also shows the COD removal of FA in solution by applying 30, 60, 90 and $120 \mathrm{~mA} \mathrm{~cm}{ }^{-2}$ at $\mathrm{Nb} / \mathrm{BDD}$ anode in $\mathrm{H}_{2} \mathrm{SO}_{4}$. Results clearly showed that, COD removal increases when an increase on the $j$ is attained. At both acidic medium, no enough concentration of oxidants is formed at $30 \mathrm{~mA} \mathrm{~cm}{ }^{-2}$. Meanwhile, when $j$ increases, the production of ${ }^{\circ} \mathrm{OH} / \mathrm{H}_{2} \mathrm{O}_{2}$ radicals in $\mathrm{HClO}_{4}$ and ${ }^{\circ} \mathrm{OH} / \mathrm{S}_{2} \mathrm{O}_{8}{ }^{2-}$ in $\mathrm{H}_{2} \mathrm{SO}_{4}$ are favored, increasing significantly the mineralization of FA. Generally speaking, the behavior observed at $\mathrm{H}_{2} \mathrm{SO}_{4}$ is similarly achieved at $\mathrm{HClO}_{4}$ (see, Figure 6) because of the small chemical structure of FA, favoring mainly the formation of $\mathrm{CO}_{2}$ (Eq. 20) with any strong oxidant formed at the electrode:

$$
\begin{aligned}
& \mathrm{HCO}_{2} \mathrm{H}+2^{\cdot} \mathrm{OH} / 2 \mathrm{H}_{2} \mathrm{O}_{2} \rightarrow \mathrm{CO}_{2}+2 \mathrm{H}_{2} \mathrm{O} \\
& \mathrm{HCO}_{2} \mathrm{H}+2^{\circ} \mathrm{OH} / \mathrm{S}_{2} \mathrm{O}_{8}{ }^{2-} \rightarrow \mathrm{CO}_{2}+2 \mathrm{H}_{2} \mathrm{O}
\end{aligned}
$$

From these experiments, it can be proposed that when the electrochemical incineration is mediated solely by ${ }^{\circ} \mathrm{OH}$ specie, degradation has a close behavior to a heterogeneous electrochemical reaction, due to the physisorbed ${ }^{\circ} \mathrm{OH}$ radicals onto the electrode. In the other hand, in the presence of sulfates the degradation reaction occurs both homogeneously with $\mathrm{S}_{2} \mathrm{O}_{8}{ }^{2-}$ anion and heterogeneously by means of the physisorbed ${ }^{\circ} \mathrm{OH}$ radicals, boostering the organic compounds elimination.

From Eq. 11, total current efficiency (TCE) values were estimated (Figure 7) for the electrochemical incineration of AA, OA and FA using $\mathrm{Nb} / \mathrm{BDD}$ in $\mathrm{H}_{2} \mathrm{SO}_{4}$ after $240 \mathrm{~min}$, and these were compared with the values obtained using $\mathrm{HClO}_{4}$. According to the results, the electrical energy furnished for the electrochemical incineration of AA is more efficiently employed than the other experiments. In fact, good TCE values were obtained for the elimination of AA when 30, 60 and $90 \mathrm{~mA} \mathrm{~cm}^{-2}$ were applied in $\mathrm{H}_{2} \mathrm{SO}_{4}$. This indicates that, the elimination is gradually performed via the participation of ${ }^{\circ} \mathrm{OH}$ and persulfate ${ }^{32}$ in a catalytic way increasing degradation by homogeneous reactions. Over $90 \mathrm{~mA} \mathrm{~cm}^{-2}$, the TCE decreased notably (less than $50 \%$ ), indicating that oxygen evolution is the main electrochemical reaction. For this carboxylic acid and $\mathrm{HClO}_{4}$ medium, again higher
TCE values were obtained, but only with 60 and $90 \mathrm{~mA} \mathrm{~cm}^{-2}$ indicating that in this range of $j$, the ${ }^{\circ} \mathrm{OH}$ are produced efficiently. As observed in $\mathrm{H}_{2} \mathrm{SO}_{4}$ media, higher values of $j$ favored oxygen evolution and lower did not generate enough ${ }^{\circ} \mathrm{OH}$ radicals or $\mathrm{H}_{2} \mathrm{O}_{2}$ is formed which do not oxidizes efficiently AA. In the case of OA, it shown to be a more recalcitrant acid than AA and TCE values close to $40 \%$ were the maximal values obtained in $\mathrm{HClO}_{4}$ media using the highest current density values. Conversely, in $\mathrm{H}_{2} \mathrm{SO}_{4}$ media, more than $50 \%$ is achieved by applying 90 and $120 \mathrm{~mA} \mathrm{~cm}^{-2}$ indicating the participation of persulfate improves the elimination. It is well known that one of the most recalcitrant carboxylic acids during organic matter degradation is oxalic acid and is generally detected in the electroincineration using BDD electrodes, ${ }^{5}$ for this reason, it was not efficiently eliminated. For FA, TCE values increased again in $\mathrm{H}_{2} \mathrm{SO}_{4}$ to values close to $90 \%$ at low current densities $\left(60 \mathrm{~mA} \mathrm{~cm}^{-2}\right)$ and decreases as result of oxygen evolution when current density increases; FA had a similar behavior to $\mathrm{AA}$ in $\mathrm{HClO}_{4}$.
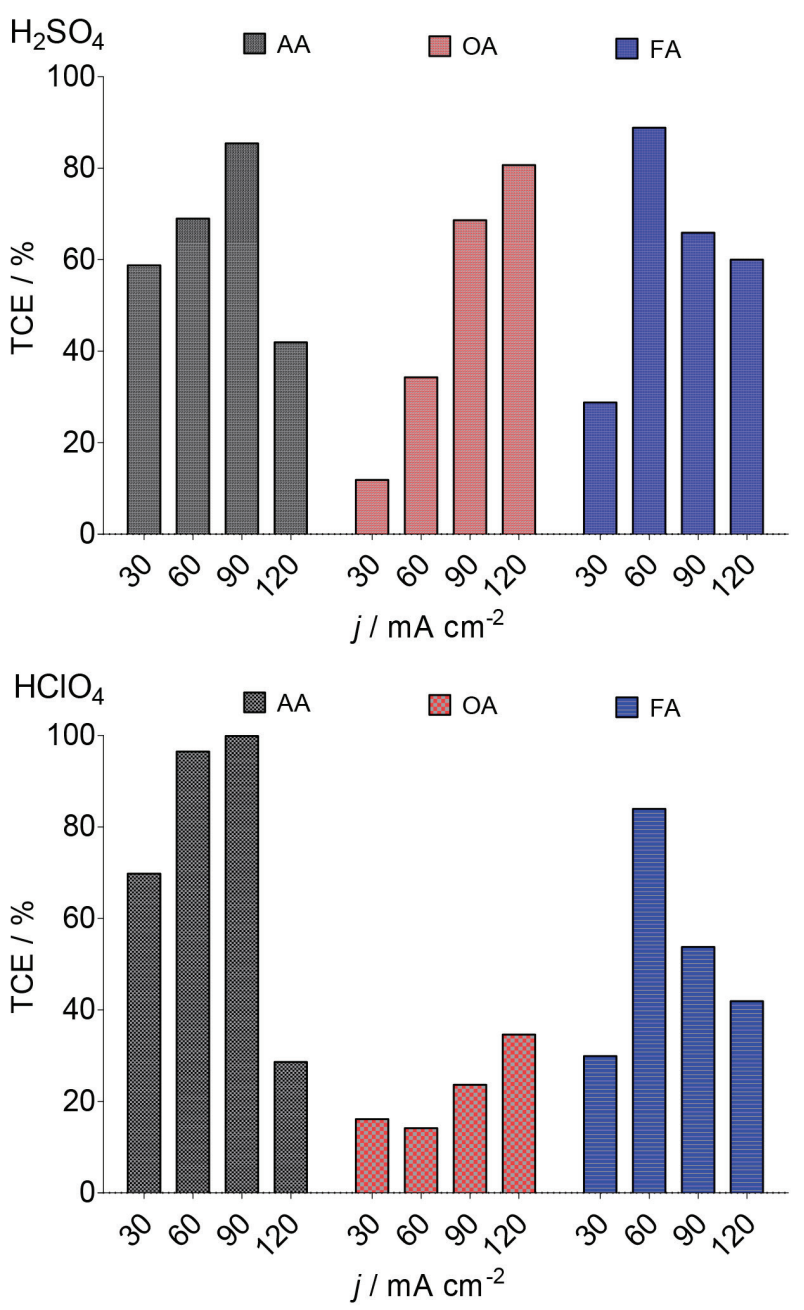

Figure 7. TCE values as a function of applied j during $E O$ of $A A, O A$ and FA in $0.25 \mathrm{~mol} \mathrm{~L}^{-1} \mathrm{H}_{2} \mathrm{SO}_{4}$ and $0.25 \mathrm{~mol} \mathrm{~L}^{-1} \mathrm{HClO}_{4}$ by using $\mathrm{Nb} / \mathrm{BDD}$ anode estimated at 240 min of electrolysis

\section{Mineralization of the short chain carboxylic acids}

The mineralization current efficiency (MCE) was determined using equation 12, which takes into account the change on TOC during the electrolysis. Table 1 shows TOC removals in both supporting electrolytes studied. In the case of FA in both $\mathrm{H}_{2} \mathrm{SO}_{4}$ and $\mathrm{HClO}_{4}$, it was at low $j$ values almost entirely mineralized reaching similar 
Table 1. Efficiency parameters: energy consumption (calculated at $240 \mathrm{~min}$ of electrolysis), TOC removal and mineralization current efficiency (calculated at $240 \mathrm{~min}$ of electrolysis)

\begin{tabular}{|c|c|c|c|c|c|c|c|}
\hline \multirow[t]{2}{*}{ Carboxylic acid } & \multirow{2}{*}{$\begin{array}{c}j \\
\left(\mathbf{m A} \mathbf{c m}^{-2}\right)\end{array}$} & \multicolumn{2}{|c|}{ 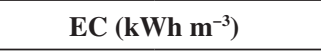 } & \multicolumn{2}{|c|}{ TOC removal (\%) } & \multicolumn{2}{|c|}{$\operatorname{MCE}(\%)$} \\
\hline & & $\mathrm{H}_{2} \mathrm{SO}_{4}$ & $\mathrm{HClO}_{4}$ & $\mathrm{H}_{2} \mathrm{SO}_{4}$ & $\mathrm{HClO}_{4}$ & $\mathrm{H}_{2} \mathrm{SO}_{4}$ & $\mathrm{HClO}_{4}$ \\
\hline \multirow[t]{4}{*}{ FA } & 30 & 18.82 & 18.10 & 46.84 & 44.49 & 101.75 & 97.40 \\
\hline & 60 & 43.97 & 43.30 & 71.53 & 73.74 & 77.69 & 80.71 \\
\hline & 90 & 76.46 & 69.98 & 78.82 & 86.41 & 57.08 & 63.06 \\
\hline & 120 & 113.10 & 112.70 & 88.07 & 90.25 & 47.83 & 49.40 \\
\hline \multirow[t]{4}{*}{ AA } & 30 & 18.34 & 19.06 & 87.83 & 5.66 & 110.2 & 24.82 \\
\hline & 60 & 47.81 & 47.14 & 49.85 & 16.15 & 104.19 & 35.43 \\
\hline & 90 & 73.44 & 78.19 & 31.85 & 22.87 & 82.72 & 33.45 \\
\hline & 120 & 116.54 & 117.12 & 42.66 & 24.63 & 83.09 & 27.02 \\
\hline \multirow[t]{4}{*}{$\mathrm{OA}$} & 30 & 17.77 & 17.71 & 40.21 & 3.25 & 90.07 & 3.23 \\
\hline & 60 & 41.47 & 42.43 & 44.82 & 44.61 & 37.15 & 22.20 \\
\hline & 90 & 72.29 & 69.26 & 58.79 & 70.84 & 32.49 & 23.50 \\
\hline & 120 & 105.84 & 104.45 & 71.21 & 83.88 & 29.52 & 20.87 \\
\hline
\end{tabular}

MCE values. At the higher $j$ values, the process was limited by mass transport at the end of the process showing a decrease in the MCE. This confirmed that secondary reactions (such as oxygen evolution) occurs in concomitance as was discussed previously. ${ }^{25,33-35}$

For AA, MCE was significantly high in $\mathrm{H}_{2} \mathrm{SO}_{4}$ than that achieved in $\mathrm{HClO}_{4}$, but it was achieved at lower $j$. This indicates that the mineralization of organic matter (from AA molecule) to $\mathrm{CO}_{2}$ and water, is accomplished in slower, suggesting that it is converted to other simpler compounds that limit the EO process or/and this reaction is in competition with oxygen evolution..$^{24,33,34}$ In the case of OA, lower mineralization is achieved at 30 and $60 \mathrm{~mA} \mathrm{~cm}^{-2}$ at both supporting electrolytes. However, an increase on the $j$ promotes an increase on the mineralization level ${ }^{29}$ after 240 min of electrolysis (Table 1). This result confirms the COD removal efficiencies achieved in $\mathrm{H}_{2} \mathrm{SO}_{4}$ and $\mathrm{HClO}_{4}$, but in the case of sulfuric acid, the participation of strong oxidants in reaction cage ( $\mathrm{OH}$ and $\mathrm{S}_{2} \mathrm{O}_{8}{ }^{2-}$ ) is attained. However, it is evident that, the mineralization of $\mathrm{OA}$ into $\mathrm{CO}_{2}$ and $\mathrm{H}_{2} \mathrm{O}$ is not complete favored due to the complexity of the OA structure. ${ }^{19-21}$

\section{Efficiency parameters}

In order to evaluate the efficiency of EO, we compare the results obtained by the energy consumption (EC), at the end of each one of the electrochemical treatments. Table 1 also shows the $\mathrm{EC}$ required for removing AA, OA and FA using Nb/BDD anode. As can be observed, during the electrolysis of synthetic wastewater solutions, EC is directly proportional to the $j$ applied, then, an increase on $j$ spent higher electrical energies. Also, EC is independent of the carboxylic acid degraded because similar values were achieved. However, when EC is compared with the \% COD removed at each one of the carboxylic acids, it is evident that higher removal efficiencies were achieved for FA oxidation with lower EC. Meanwhile, similar behavior is observed between AA and OA, in terms of COD removals at the end of the electrolysis, but the increase on the energy requirements is directly proportional for OA elimination. Conversely, a significant variation of EC is achieved at AA oxidation with different COD removals.

\section{CONCLUSIONS}

The supporting electrolyte has important role on the oxidative process pathway due to the strong oxidants produced at $\mathrm{Nb} / \mathrm{BDD}$ surface. In fact, in the case of $\mathrm{HClO}_{4}$, higher concentrations of hydroxyl radicals and hydrogen peroxide were detected, whereas persulfate production and hydroxyl radicals are the main reactions when $\mathrm{H}_{2} \mathrm{SO}_{4}$ is used in solution as electrolyte. The formation of persulfate is performed due to the direct oxidation of sulfate on diamond electrode surface, but the reaction between hydroxyl radicals and sulfate ion is also feasible. This reaction can be conveniently for electrochemical incineration used, treating a synthetic solution containing carboxylic acids, separately. The experiments with sulfuric acid demonstrated a faster removal of organic matter, in terms of COD and TOC, which can be attributed to the simultaneous action of persulfates and hydroxyl radicals. Comparing the results using $\mathrm{H}_{2} \mathrm{SO}_{4}$ and $\mathrm{HClO}_{4}$, similar behaviors were achieved in terms of electrochemical degradation for FA, and AA, nevertheless, OA showed to be a more recalcitrant organic compound.

\section{ACKNOWLEDGEMENTS}

Financial support from National Council for Scientific and Technological Development (CNPq - 465571/2014-0; CNPq - 446846/2014-7 and CNPq - 401519/2014-7) and FAPESP (2014/50945-4) are gratefully acknowledged. Carlos A. MartínezHuitle acknowledges the funding provided by the Alexander von Humboldt Foundation (Germany) and Coordenação de Aperfeiçoamento de Pessoal de Nível Superior (Brazil) as a Humboldt fellowship for Experienced Researcher (88881.136108/2017-01) at the Johannes Gutenberg-Universität Mainz, Germany. B. A. FrontanaUribe thanks funding provided by PAPIIT-UNAM Project 208919 and CONACYT-MEXICO Project A1-5-18230.

\section{REFERENCES}

1. Martínez-Huitle, C. A.; Panizza, M.; Curr. Opin. Electrochem. 2018, 11, 62.

2. Martínez-Huitle, C. A.; Rodrigo, M. A.; Sirés, I.; Scialdone, O.; Chem. Rev. 2015, 115, 13362.

3. Brillas, E.; Sirés, I.; Oturan, M. A.; Chem. Rev. 2009, 109, 6570.

4. Brillas, E.; Martínez-Huitle, C. A.; Appl. Catal., B 2015, 166-167, 603.

5. Panizza, M.; Cerisola, G.; Chem. Rev. 2009, 109, 6541.

6. Espinoza-Montero, P. J.; Vasquez-Medrano, R.; Ibanez, J. G.; FrontanaUribe, B. A.; J. Electrochem. Soc. 2013, 160, G3171. 
7. Michaud, P. A.; Panizza, M.; Ouattara, L.; Diaco, T.; Foti, G.; Comninellis, C.; J. Appl. Electrochem. 2003, 33, 151.

8. Davis, J.; Baygents, J. C.; Farrell, J.; Electrochim. Acta 2014, 150, 68.

9. Garcia-Segura, S.; Dos Santos, E.V.; Martínez-Huitle, C.A.; Electrochem. Commun. 2015, 59, 52.

10. Brito, C. N.; De Araújo, D. M.; Martínez-Huitle, C. A.; Rodrigo, M. A.; Electrochem. Commun. 2015, 55, 34.

11. Cotillas, S.; Clematis, D.; Cañizares, P.; Carpanese, M. P.; Rodrigo, M. A.; Panizza, M.; Chemosphere 2018, 199, 445.

12. Clematis, D.; Abidi, J.; Cerisola, G.; Panizza, M.; ChemElectroChem, 2019, 6, 1794.

13. Klidi, N.; Clematis, D.; Carpanese, M. P.; Gadri, A.; Ammar, S.; Panizza, M.; Sep. Purif. Technol. 2019, 208, 178.

14. Tasca, A. L.; Puccini, M.; Clematis, D.; Panizza, M.; Environ. Pollut., 2019, 251, 285

15. Dos Santos, E. V.; Sáez, C.; Martínez-Huitle, C. A.; Cañizares, P.; Rodrigo, M. A.; Electrochem. Commun. 2015, 55, 26.

16. Cañizares, P.; García-Gómez, J.; Lobato, J.; Rodrigo, M. A.; Ind. Eng. Chem. Res. 2003, 42, 956.

17. Martínez-Huitle, C. A.; Ferro, S.; De Battisti, A.; J. Appl. Electrochem. 2005, 35, 1087.

18. Cañizares, P.; Paz, R.; Sáez, C.; Rodrigo, M.A.; Electrochim. Acta 2008 , $53,2144$.

19. Ferro, S.; Martínez-Huitle, C. A.; De Battisti, A.; J. Appl. Electrochem. 2010, 40, 1779

20. Fierro, S.; Abe, K.; Comninellis, C.; Einaga, Y.; J. Electrochem. Soc.
2011, 158, F183.

21. Comninellis, C.; Electrochim. Acta 1994, 39, 1857.

22. Nogueira, R. F. P.; Oliveira, M. C.; Paterlini, W. C.; Talanta 2005, 66, 86.

23. Oliveira, M. C.; Nogueira, R. F. P.; Neto, J. A. G.; Jardim, W. F.; Rohwedder, J. J. R.; Quim. Nova 2001, 24, 188.

24. Liang, C.; Huang, C.-F.; Mohanty, N.; Kurakalva, R. M.; Chemosphere 2008, 73, 1540

25. Gandini, D.; Mahé, E.; Michaud, P. A.; Haenni, W.; Perret, A.; Comninellis, C.; J. Appl. Electrochem. 2000, 30, 1345.

26. Panizza, M.; Cerisola, G.; Appl. Catal., B 2007, 75, 95.

27. Michaud, P. A.; Mahé, E.; Haenni, W.; Perret, A.; Comninellis, C.; Electrochem. Solid-State Lett. 2000, 3, 77.

28. Kapałka, A.; Fóti; G.; Comninellis, C.; J. Appl. Electrochem. 2008, 38, 7.

29. Martínez-Huitle, C. A.; Ferro, S.; De Battisti, A.; Electrochim. Acta 2004, 49, 4027

30. Panizza, M.; Cerisola, G.; J. Electroanal. Chem. 2010, 638, 28.

31. Kapałka, A.; Lanova, B.; Baltruschat, H.; Fóti, G.; Comninellis, C.; J. Electrochem. Soc. 2008, 155, E96.

32. Rodrigo, M. A.; Cañizares, P.; Sánchez-Carretero, A.; Sáez, C.; Catal. Today 2010, 151, 173.

33. Kapałka, A.; Lanova, B.; Baltruschat, H.; Fóti, G.; Comninellis, C.; Electrochem. Commun. 2008, 10, 1215.

34. Weiss, E.; Groenen-Serrano, K.; Savall, A.; Comninellis, C.; J. Appl. Electrochem. 2007, 37, 41.

35. Labiadh, L.; Barbucci, A.; Cerisola, G.; Gadri, A.; Ammar; S.; Panizza, M.; J. Solid State Electrochem. 2015, 19, 3177. 